\title{
Analisis Kekuatan Program Kesehatan
}

\section{(Jaminan Kesehatan Nasional)}

Dini (70200120015)

Kesehatan Masyarakat

Fakultas Kedokteran dan Ilmu Kesehatan

Universitas Islam Negeri Alauddin Makassar

\section{Evidence Based Analysis}

Terdapat waktu tunggu pelayanan resep yang belum mencapai standar pelayanan minimal (SPM), yaitu untuk resep non racikan sebanyak 49\% dan resep racikan sebanyak $47,1 \%$. Hal tersebut belum sesuai dengan dalam Kepmenkes Nomor 129/Menkes/SK/II/2008 tentang Standar Pelayanan Minimal Rumah Sakit. Waktu lama tunggu pelayanan resep non racikan mempunyai presentase $0 \%$ sesuai standar dan obat dengan presentase $67 \%$ sesuai dengan standar.

\section{Field Force Analysis}

Sebab dari tidak sesuainya waktu tunggu pelayanan resep dengan SPM pada tiap jenis resep mempunyai sebab yang berbeda. Untuk waktu tunggu pelayanan resep non racikan, faktor yang mengakibatkan semakin lamanya pelayanan resep yaitu terdapat pada proses etiket dengan rata-rata 03 menit 31 detik dengan proses etiket tercepat 47 detik dan proses etiket terlama 12 menit. Waktu yang diperlukan dalam proses etiket dapat semakin lama dikarenakan petugas etiket harus menuliskan aturan pakai pada obat sesuai dengan resep pengisian pada KCO pasien. Hal-hal yang perlu ditulis petugas dalam KCO pasien meliputi: identitas pasien (nama pasien, dan nomor rekam medis), tanggal pengambilan obat, asal poliklinik, dokter yang melayani, resep obat, tanggal kembali priksa, dan/atau tanggal ke laboratorium. 
Adapun waktu jeda yang lain yang menjadi faktor semakin lamanya pelayanan resep non racikan yaitu, waktu jeda dari jeda pengambilan obat ke proses etiket, dimana pada jeda tersebut mempunyai waktu nilai maksimal jeda terlama dibanding dengan nilai maksimal pada proses maupun jeda di pelayanan resep non racikan. Sebab dari waktu jeda yang menjadi semakin lama dikarenakan kurang disiplinnya petugas dalam manajemen urutan nomor resep.

Jadi dapat disimpulkan faktor penyebab proses peracikan menjadi proses yang paling lama karena peralatan penunjang yang digunakan saat memasukan obat yang telah diracik ke dalam kapsul meenggunakan alat yang sederhana.

\section{Institutional Strengthening Analysis}

Aspek kepesertaan dibahas dalam Pasal 4 huruf (g) UU SJSN, dimana dalam melaksanakan jaminan sosial (JKN) menggunakan prinsip kepesertaan bersifat wajib, yakni artinya mengharuskan seluruh penduduk menjadi peserta JKN. Tetapi, dalam Pasal 13 - Pasal 17 UU SJSN hanya menjelaskan tiga kepesertaan dalam jaminan sosial yakni kepesertaan pemberi kerja, pekerja dan masyarakat miskin atau peserta penerima bantuan iuran (PBI). Sedangkan, tujuh tahun kemudian, Pasal 14 UU BPJS Kesehatan menjelaskan bahwa peserta program JKN adalah "setiap orang, termasuk orang asing yang bekerja paling singkat enam bulan di Indonesia". Pasal 19 UU BPJS menyebutkan nomenklatur baru, yakni Peserta Bukan Pekerja.

PP No.101/2012 muncul lebih dulu untuk melaksanakan ketentuan pembayaran iuran bagi Peserta PBI Program JKN. Bantuan iuran pemerintah ini diberikan kepada fakir miskin dan orang tidak mampu. Kriteria peserta PBI ditetapkan oleh Menteri/Lembaga yang menyelenggarakan urusan pemerintahan di bidang statistik melakukan pendataan yang diverifikasi dan divalidasi oleh Menteri (Kementerian Sosial) untuk dijadikan data terpadu yang dirinci per.provinsi dan kabupaten/kota. Data terpadu ini kemudian diserahkan kepada Kemnterian 
Kesehatan untuk didaftarkan menjadi peserta BPJS Kesehatan. Iuran peserta PBI bersumber dari APBN. Perpres No. 82/2018 tentang Jaminan Kesehatan adalah Perpres perubahak ke-3 dari Perpres No.12/2013, menjelaskan bahwa dalam kepesertaan program JKN terdiri dari dua kelompok, yakni peserta PBI (fakir miskin dan orang tidak mampu dengan ditetapkan Kementerian Sosial), dan peserta Non-PBI (PPU3 , PBPU4 , dan BP5 ).

\section{Need Community Analysis}

Pelayanan rawat jalan merupakan salah satu manfaat yang dijamin oleh program Jaminan Kesehatan Nasional (JKN). Tujuan utama program JKN adalah meningkatkan aksesibiltas masyarakat terhadap pelayanan kesehatan yang sesuai dengan kebutuhan.

Manfaat Program Jaminan Kesehatan Nasional bagi peserta adalah (1) Pelayanan Kesehatan diberikan di fasilitas kesehatan milik Pemerintah atau swasta yang menjalin kerjasama dengan badan penyelenggara jaminan sosial; (2) dalam keadaan darurat, pelayanan kesehatan dapat diberikan pada fasilitas kesehatan yang tidak menjalin kerjasama dengan badan penyelenggara jaminan sosial; (3) Badan penyelenggara jaminan sosial wajib memberikan kompensasi (dapat berupa uang tunai) untuk memenuhi kebutuhan medik peserta yang berada di daerah yang belum tersedia fasilitas kesehatan yang memenuhi syarat; (4) layanan rawat inap di Rumah Sakit diberikan di kelas standar; (5) Badan penyelenggara jaminan sosial menjamin obat-obatan dan bahan medis habis pakai dengan mempertimbangkan kebutuhan medik, ketersediaan, efektifitas, dan efisienssi dari obat atau bahan medis habis pakai sesuai ketentuan peraturan perundangan; (6) dalam pengembangan pelayanan kesehatan, Badan Penyelenggara Jaminan sosial menerapkan sistem kendali mutu, sistem kendali biaya dan sistem pembayaran untuk meningkatkan efektifitas dan efisiensi jaminan kesehatan srta untuk mencegah penyalahgunaan pelayanan kesehatan; dan (7) untuk jenis pelayanan yang dapat menimbulkan penyalahgunaan pelayanan, peserta dikenakan turun biaya. 